\title{
Public Service InnovationThrough the Application of Smart Kampong Concept in Local Government Banyuwangi
}

\author{
Puji Wahono \\ Faculty of Social and Political Sciences \\ Universitas Jember \\ Jember, Indonesia \\ wahono.fisip@unej.ac.id
}

\begin{abstract}
Banyuwangi is a local government with the total area 94 times the size of the city of Banda Aceh and eight times the size of Jakarta. It consists of 24 districts and 189 Kampong (Villages). Therefore, people who wish to gain local government services have to travel for two to four hours to get it. It is certainly not in line with the modern concept of public service quality; fast and efficient. In order to overcome it, the local Governments perform public service innovation by applying the concept of Smart Kampong, using information technology application. The purpose of this study is to uncover reasons for the selection of the concept (instead of smart city), by linking the unique facts with theories. This innovation aside make public service more accessible, and also open access to a wider market.
\end{abstract}

Keywords-Smart Kampong, public service, innovation, local government, Banyuwangi.

\section{INTRODUCTION}

Banyuwangi Local Government is a bit different from the municipality, mainly due to its very wide area. If other municipality (city) is generally composed of three to five subdistricts, Banyuwangi has 24 subdistricts and 189 villages, called Kampong. Thus, the Socio-economic characteristics of Banyuwangi also different from the other in general. If the city is referring more to an urban area, Banyuwangi is dominated mostly by rural area. The level of education and rural cultures still firmly attached to the majority of Banyuwangi people. In the economic sphere, if the economic activity in the city in general is dominated by the service sector, Banyuwangi is mostly dominated by agricultural sector.

Problems faced Banyuwangi thereby also very much different from faced by the city. Congestion, littering, the people settlement, which is generally faced by cities; is causing relatively little trouble in Banyuwangi. Instead, the main problem faced by Banyuwangi is its vast area and the difficulty of its people to access the community services from local government, because they are very far from public service center. If the world's cities are being transformed by implementing smart city, to improve public services, then Banyuwangi innovate itself by applying information technology (ICT) through the application of a concept called Smart Kampong. The term smart Kampong is chosen because of the differences with the city as described above.
The research question in this study is, why and how Smart Kampong concept in Banyuwangi is implemented, instead of smart city, and what are the implications for people's access to public services and the market? The purpose of this study is to answer in more detail about why local government in Banyuwangi apply the Information and Communication Technology (ICT) through the Kampong.

This study is using qualitative strategy [1], followed by empirical data to the analysis and policy overview. The qualitative data obtained through in-depth interviews (depth interview) with a number of related government agencies and actors in the business society. They were chosen at random by using snowball sampling approach. The study was conducted in 2015 and early 2016 in Banyuwangi, East Java Province.

II. THEORETICAL \& CONCEPTUAL REVIEW

Sahoo [2] defines innovation as the creation of new knowledge, ideas and creative process with insights and solutions for better performance in socio-economic values. It does not matter whether it is adding commercial values but it should have a competitive and collaborative impact in finding solutions for various socio-economic challenges and effective governance system. According to Drucker [3] innovation is change that creates a new dimension of performance.

Strupf says [4] the conventional wisdom is that government decentralization policy promotes innovation because it allows for simultaneous several experiments by local Governments. As Galle and Leahy [5] quote from Susan Rose-Ackerman (1980), innovations in government produce positive externalities for other jurisdictions. Theory predicts, that local government will tend to produce a lower than optimal amount of innovation, as Officials will prefer to free ride on innovation by others.

Sahoo [6] says innovation has became a critical driver of growth, productivity and competitiveness. Today we need innovation to meet the increasing challenges and necessities. Whether it is change or creativity, innovation is vital and important for the economic growth and progress of social well-being. The diverse necessities such as environmental problems, climate change, food, water, healthcare, education, housing, energy and electricity, without innovation, we can not find a sustainable solution to the longneeded problems in this hyper techno-science world.

To solve the problems caused by the vastness by its area, Banyuwangi chose the concept of Smart Kampong, which 
according to Anas [7] have seven focus namely: (a) Smart Economy, (b) Smart Mobility, (c) Smart People, (d) Smart Environment, (e) Smart Living, (f) Smart Governance, and (g) Smart Farming. Of the seven of that focus, the most unique is the Smart People, those are people who prefer to count on the local production rather than relying on others.

Smart Kampong to Anas [8] is not simply the application of ICT but also accompanied by learning activities. Village Hall (Balai Desa) will serve as a place to learn culture, arts, and others. As a pilot project, the government selected 24 villages and after that it will continue to be added until the entire village in Banyuwangi (189 villages) is covered.

Aside from the Community Empowerment Board and Village Offcial (BPM-PD), the program will also be tackled by the Regional Division of Education, Regional Development Planning Board (Bappeda), and the Regional Division of Culture and Tourism (Disbudpar).

There are many innovations done by municipality or local government all over the world using the information technology, called smart city. This study wants to discuss the similar innovations but applied in different level of governenment in Banyuwangi, known as Smart Kampong.

\section{INFRASTRUCTURE DEVELOPMENT}

Banyuwangi is geographically located at the eastern tip of the island of Java, it referred to itself as The Sunrise of Java. The border in the east of Banyuwangi is the Bali Strait. The total area of Banyuwangi is $5782 \mathrm{~km}^{2}$, this means it is about 94 times the area of Banda Aceh, 34 times the area of Bandung, 15 times the size of the city of Surabaya, and 8 times the size of the city of Jakarta. Banyuwangi is composed of 24 subdistricts, 198 villages or kampong and inhabited by 1.6 million inhabitants.

Public service innovation in Banyuwangi began about four years ago, when PT. Telekomunikasi Indonesia, Tbk (Telkom) transforming Banyuwangi into a city that is aware to the information communication technology (ICT). With the concept of Digital Society, the district begin the transformation of the public service activities as well as internet-based society.

Starting with the installation of 1,100 points WiFi in Banyuwangi, since then, the number of supporting applications began to takes place such as IndiSchool (High school), IndiPreneur (Internet for small and medium enterprises), IndiFinance (to access the payment). As a city of religious scholar, Banyuwangi also provide e-Zakat application that will allow people to fulfill the obligation of zakat (for Moslem people).

Those applications make Banyuwangi as the first district in Indonesia to implement digital technology. It makes the connection to the working units in local government (SKPD) and public services easier. Via e-Audit for example, the Supreme Audit Agency (BPK) in province level (Surabaya) for instance, can easily perform an audit, because the administrative systems are directly connected.

According to Suprayogi [9], Head of Transportation Department unit, Banyuwangi Local Government allocated Rp2 billion per year for internet shopping and broadband networks. Under the policy, the villages that are located far from access to public services, are now beginning to get the Internet via $\mathrm{WiFi}$.

To complement the public service through the application of this technology, local government Banyuwangi together with PT. Telkom is building a park that will be equipped with 10 digital $\mathrm{WiFi}$, on the Boom beach, in the center of the city with a budget of Rp1 billion.

According to Anas [10], head of of Banyuwangi local government (Regent), the development of information technology is chosen because he believes the future of society is determined by the information technology and development of broadband networks. Further, more he said, that every 10 percent growth in broadband network infrastructure, will raise economic growth by 0.8 percent.

Suprayogi said [11] that from the user side, the user amount is also growing both quantitatively and qualitatively. Those who access WiFi, recorded throughout 2014, reached 164.372 per month, increased from 97.957 the previous year. This is because the community can access WiFi in the open spaces in villages (Green Open Space) that provided by Banyuwangi local government.

Meanwhile, PT Telkom noted, in the first quarter of 2015 , the average number of access of WiFi per month in Banyuwangi increased by 132 percent over the previous year. In 2014 the average access of $\mathrm{WiFi}$ provided by PT Telkom reached 290.682 per month. Even in the first quarter of 2015 the number jumped to 384.283 . [12]

The main challenge, according to Suprayogi [13], is the human resources itself. Provision of telecommunications technology infrastructure is not an easy job, but it is easier to treat. The most difficult part is to urge people to change, and it is not easy, because it concerns the habits and willingness to learn and change.

\section{IMPRoving Public SERVICES}

The Distance that the people have to go through to get public services, is becoming a concern to Banyuwangi government. It will be very inefficient if only for an ID card, residents will have to go to a three-hour car ride. This is the reason for the introduction of Internet-based application that begins with the word Smart, like Smart Economy, Smart Mobility, Smart People, Smart Environment, Smart Living, Smart Governance, and Smart Farming [14].

The village government budgeting system integrated in the network or online by e-Village Budgeting name $(e-V B)$, launched in late 2014. This $e-V B$ is one of the innovations to the transparency of budgeting and monitoring of rural development at the same time. With this system, there are synergies in finance and development at the kampong level with the district, which is expected to be able to create harmony.

There are three important parts of $e-V B$ applications, namely planning, governance, and evaluation. This system cut the chain of manual budgeting at the village level. The target is that all of the villages, or 189 villages in Banyuwangi will be implementing these applications at the end of 2015 . e-VB is connected directly to the Community Empowerment Board and Village Government (BPM-PD), along with the District Development Planning Agency (Bappekab) [15]. 
Disbursement through this system can be monitored easily. It can be once every semester or quarter. Another advantage of this application is that it can anticipate the possibilities of misuse of the budget. While e-Monitoring (eVM) application can make supervising more efficient, both physical and non-physical. As an example, of the 4000 program in 189 villages, each program takes at least three visits, so that the total visits required is 12,000 times [16].

E-VB system is ready both human resources and networks and all is online based. As well as e-VM, the whole system will be monitored in real time. In the framework of monitoring based e-VM, for example, the district will take a photo of the implementation of programs, such as for the construction of roads ranging from 0 percent (the condition has not improved) to 100 percent (repaired) and upload it online.

The network is also make things easier for health services in every health centers and hospitals. A birth certificate can be processed simultaneously in the event of deliveries in subdistrict health centers (Puskesmas), community health services because the network is already integrated. It is expected that the number of rooms for inpatient available in every health center and hospital can be directly known to the public, so that everything can be handled [17]

According to Anas [18], overall the Smart Kampong can be categorized into two models of innovation in order to improve village governance: (a) Approach based on information technology and communication by $e-V B$ and $e$ $V M$; (b) Institutional arrangements, related to delegation of authority from the higher rank in the chain of command to the lower rank of officials to conduct more intensive programs supervision in the village.

ICT infrastructure became the fifth most important infrastructural in Banyuwangi in addition to Roads, Bridges, Airports and Ports. This is in line with the five priorities for ICT development in the design of a large village which include e-government, e-health, e-education, e-logistics, and e-procurement.

For e-health services, there are ambulances that are connected with the server at the local government office. If the people need service, they simply press the phone number provided and the request will be directed to the location of the nearest assistance.

Through ICT and the concept of Smart Kampong, Banyuwangi has been able to innovate public services for health, education, population, economy, and administration. Service processes that previously took 1-2 days can be trimmed to 1-2 hours, for example for mailing.

The big budget needs for infrastructure development, is from the government budget, other organizations and also CSR funds from PT Telkom, amounting to Rp10 billion that was used to install WiFi in order to support the digitization program with adequate bandwidth [19]

Innovation in public services applied by Banyuwangi is providing online public services integrated by the local government and the utilization of information technology networks built by the local government for the people. The emphasis is more to the people, and they should be able to take advantage of information technology networks and involved in the development so as to create a digital society. In 2013
Banyuwangi local government get 1 st place in Digital Society and the user point $\mathrm{WiFi}$ is the largest in Indonesia [20].

V. OPENING THE MARKET ACCESS

Digitizing the kampong or villages through the application of ICT since 2012 makes Banyuwangi as a local government that is based on digital technology. This policy is not only open the access to public services but also to open market access. According Kartiono [21], Head of Department of Cooperatives and SMEs Unit, since many SMEs in the villages utilizing online sales, it is broaden its sells within the country and also abroad. The community really taught to use the Internet as a distribution channel of their merchandise products. Farm animals such as goats and cows are now marketed online.

On tourism, the promotion is done by making the operating system based on Android to trim the promotion fund In the past five years, the tourism sector in Banyuwangi continued to thrive to offer a program that are focusing on nature and culture and is packed with alot of festivals. As the result, tourist visits to Banyuwangi increased significantly. Domestic tourists, the number jumped 161 percent from 651,500 people (2010) to 1,701,230 million people (2015). Foreign tourists increased by $210 \%$ from the range of 13,200 (2010) to 41,000 (2015) [22].

Banyuwangi in early 2016 received an award from the UN Agency for Tourism, UNWTO (United Nations World Tourism Organization) in UNWTO 12th Forum Awards in Madrid, Spain. Banyuwangi awarded an award in the Excellence and Innovation in Tourism for the category of 'Innovation in Public Policy and Governance'. Now, through the application Banyuwangi In Your Hand, that can be downloaded for free via the Google Play Store and App Store, users can obtain information tourist spots and industrial creative interest in Banyuwangi completely.

Overall, according to Anas [23] Smart Kampong application in Banyuwangi, can slowly move the economy of the village community. It is also proven by the increase in income per capita in the last three years have increased continuously and then managed to change the image of Banyuwangi to be more modern than previously thought or as an under developed area.

Application of ICT through the development of the concept of smart village will be able to enhance economic competitiveness, encourage active community participation in development and environmental preservation.

Fonny [24] Sayuwiwit batik artisans in the kampong Temenggungan, Banyuwangi claimed to have benefited from the development of the Internet in Banyuwangi. The pictures of batik products that have been on display in the showroom, without her knowing, are uploaded to social media by the buyers. That information is then spread and eventually many prospective customers come without she had to waste a lot of energy promoting batik products.

Munawaroh [25], Tropical Batik artisans, from Kampong Gendoh, Subdistrict Singojuruh, who at first is a producers of sarong beach in Bali, now has moved and live in Banyuwangi, for family reasons. Because of Its proximity to the Gendoh village Green Open Space (RTH), where people usually access the $\mathrm{WiFi}$, her business is easily recognizable in the community. Her batik market not only in Banyuwangi and 
Bali but also in Hawaii (USA) and in Japan, and she can easily send pictures and communicate in real-time including bargaining the price or the required design with her customers.

Firman [26] Godho batik artisans, Kampong Kalipuro, Subdistrict Giri, Banyuwangi. He was very difficult to find because he is very busy doing things associated with his business. He was not worried anymore with batik marketing, because it can be done online. He also believes his business name that are displayed in various events of local governments, which are accessible online, will bring many potential buyers easily. Those buyers will be able to find his place and also the motif they want. But Firman emphasizes the need for expansion of the scope and speed of the connection.

The imperfections of the application of ICT in the Kampong is admitted by Suprayogi [27], Head of the Local Department of Transportation. He said that his office is also the headquarters of the application of smart village. According to him, Banyuwangi is still in the stage of digitizing the kampongs and it was costly. Networking is not all use fiber optic so the speed is not optimal. Application of smart village is still far away from what is in one's ideals as smart city in the world's cities.

Supanggih [28] snacks makers in Banyuwangi who knew the Internet a year ago, had always sell items at his kiosk. Once smart kampong and $\mathrm{WiFi}$ lots is available in the kampong he began to market his snacks online to various corners of the world. He said that at the beginnings his location is not permanent, due to capital constraints for the lease of business premises. Now with easy access to internet, he doesn't need to to rent a place anymore. With a simple android gadget that he had, he can sell snacks like potato chips to Bali,Surabaya and other cities.

Suradi [29], beads artisan from the Kampong Kabat, Kabat subdistrict, Banyuwangi can now offer his products online and is accessible to anyone anywhere as long as there is an Internet connection, he said. He, along with other craftsmen like Supanggih, can now be proud to be a supplier of craft shops in Yogyakarta and Bali, and Surabaya. Before the Internet, he can only supply the local area only. They both relate, during the economic crisis and the price of the dollar rose, they did not benefit very much because the price is determined by the middlemen. Now he gets more profit because he can directly relates to the buyer through an online network.

According to Purnomo [30], Head of Industry and Trade Unit as well as Kartiono [31] Head of Department of Cooperatives and SMEs Unit in Banyuwangi, many households and micro entrepreneurs in rural areas enjoy their new markets with their digitization (Smart Kampong) in Banyuwangi.

According Kartiono [32], it now provides a lot of guidance and trainings to prospective artisans and microenterprises who are requesting assistance for the enhancement and progress of the business, including how to use the Internet to market their products and services it sells.

Meanwhile, according to Purnomo [33], in the conditions of a free market today, it is important to create a way to protect the assets of Banyuwangi so that they are not easily duplicated by others in a way that is not justified. Therefore, he is now keen to socialize the importance of patents and intellectual property rights. He also has presented what are the things that can be categorized as the intellectual property (Haki) of Banyuwangi in front of the Director General of Haki in Jakarta.

\section{CONCLUSION}

The Application of Information Technology through the Smart Kampong concept makes public service faster and more efficient. The concept of Smart Kampong is choosen because Banyuwangi geographically cover a very wide area.

Smart Kampong concept is intended to empower the people in the Kampong (village) Level, or those who are at the lowest level in the government structure and located far from the governement offices to get a faster and more efficient public services.

Innovation through the implementation of concept Smart Kampong in Local Government Banyuwangi also has opens the access to a better public services and also to a prospective market for their products.

\section{REFERENCES}

[1] Creswell, John W. 2010. Research Design: Qulitative, Quantitative, and Mixed Methods Approaches.Third Edition. Sage Publications. Thousand Oaks California.

[2] Sahoo, Ganeswar. 2010. The Government is an Actor in Indian Government Stimulates Innovation How Innovarion. Dissertation for the Master of Science. University of Trento and Sant'Anna School of Advanced Studies (Italy).

[3] Drucker, Peter F. 1985. Innovation and Entrepreneurship. Harper Business A Division of HarperCollins Publishers.

[4] Strumpf, Koleman, S. 1999. "Does Decentralization Increase Government Policy Innovation". Papaers. Social Science Research Network (SSRN).

[5] Galle, Brian and Joseph Leahy. 2009. "Laboratories of Democracy? Policy Innovation in Decentralized Governments". Emory Law Journal. (Vol 58 Number 6).

[6] Sahoo. 2010. Op.cit.

[7] Anas, Abdullah Azwar (Banyuwangi Regent). 2015. Inside Siwi Yunita Cahyaningrum, "Tehnologi Digital Ubah Wwajah Banyuwangi". Kompas (23 Februari 2015)

[8] Ibid.

[9] Suprayogi. 2015. Chief of Department of Transportation Local Office. Interview. (07/11/2015).

[10] Anas, Abdullah Azwar. 2015. Inside Rachmatunisa http://inet. detik.com/read/2015/06/ 16/133257/2943706/ 398/bupati-pengubahwajah-banyuwangi-dengan-teknologi (Downloaded Feberuary 25, 2016).

[11] Suprayogi. 2015.Op.cit.

[12] Andriawan, Shesar. 2015. "Tiga Kota Meniti jalan Menuju Smart City". Inside http://www. beritasatu.com/nasional/244614-tiga-kota-menitijalan-menuju-smart-city.html (downloded Februari 25, 2016).

[13] Suprayogi. 2015. Opcit.

[14] Andriawan, Shesar. 2015. Opcit.

[15] Ibid.

[16] Kusbiantoro, Didik. http://jatim.antaranews.com/lihat/berita/146230/ semua-desa-di-banyuwangi-terapkan-penganggaran-online. Februari 25, 2016.

[17] Read, http://news.detik.com/jawatimur/2770096/menteri-desa-resmikane-village-budgeting-banyuwa ngi (Downloaded January 7, 2016).

[18] Anas, Abdullah Azwar. 2015. Inside Cahyaningrum. Op.cit.

[19] Kusbiantoro, Didik. 2015. Op.cit.

[20] Ibid.

[21] Kartiono. Chief Departement of Cooperative and SMEs Local Offoce Banyuwangi. Interview. June 09, 2015.

[22] Eka L., Juliant. Penerapan teknologi informasi komunikasi dalam mendukung Smart City." http://artikel-opiniku.blogspot.co.id/2015/02/ penerapan-teknologi- informasi.html. Downloaded Januari 15, 2016. 
[23] Anas, Abdullah Azwar.2015. "Konsep Smart Kampung di Kabupaten Banyuwangi" inside http://www. banyuwangipost.com/konsep-smartkampung-di-kabupaten-banyuwangi/. Downloaded, Feberuary 12, 2016.

[24] Fonny. 2015. Batik Artisan from House of Batik Sayuwuwut. Banyuwangi. Interview. June 10, 2015

[25] Munawaroh. 2015. Owner Batik Tropical in Banyuwangi. Interview. June $10,2015$.

[26] Firman. 2015. Batik Artisan Godho House of Batik. Banyuwangi. Interview. June 10, 2015.

[27] Suprayogi. Op.cit. 2015

[28] Supanggih. Inside Cahyaningrum. Op.cit. 2015

[29] Suradi. 2015. Ibid.

[30] Purnomo. Head of Industry and Trade Banyuwangi Local Office. Interview. June 09, 2015.

[31] Kartiono. Op.cit. 2015

[32] Ibid.

[33] Purnomo. Op.cit. 2015 